University of Wollongong

Research Online

Scopus Harvesting Series

$1-1-2021$

\title{
Maritime Security Cooperation Between India and Indonesia: Imperatives, Status and Prospects
}

Prakash Gopal

University of Wollongong, pg006@uowmail.edu.au

Indra Alverdian

University of Wollongong, ia779@uowmail.edu.au

Follow this and additional works at: https://ro.uow.edu.au/test2021

\section{Recommended Citation}

Gopal, Prakash and Alverdian, Indra, "Maritime Security Cooperation Between India and Indonesia: Imperatives, Status and Prospects" (2021). Scopus Harvesting Series. 1394.

https://ro.uow.edu.au/test2021/1394

Research Online is the open access institutional repository for the University of Wollongong. For further information contact the UOW Library: research-pubs@uow.edu.au 


\title{
Maritime Security Cooperation Between India and Indonesia: Imperatives, Status and Prospects
}

\author{
Abstract \\ India and Indonesia are two key emerging economies in the Indo-Pacific region-both with a strong \\ reliance on the maritime domain for sustained economic growth. After a relatively tumultuous phase in \\ their bilateral relations during the Cold War, the countries have embarked on a path of reconciliation and \\ developing stronger ties. During this phase, there has understandably been a strong focus on enhancing \\ maritime security cooperation between them, so as to obtain positive bilateral and regional outcomes. \\ This has gained impetus in recent years with congruence of thought at the political level in both New \\ Delhi and Jakarta. However, the many institutional mechanisms developed over the years have not been \\ as effective in engendering tangible security outcomes in the region. Both countries-and indeed the Indo- \\ Pacific region-would decidedly benefit from focusing on key areas of cooperation in maritime security \\ that promise mutually beneficial operational outcomes and the prospect of establishing long-term \\ cooperative mechanisms in the Indo-Pacific region.
}

\section{Keywords}

India, Indo-Pacific, Indonesia, maritime security 


\title{
Maritime security cooperation between India and Indonesia: imperatives, status, and prospects
}

\author{
Prakash Gopal and Indra Alverdian
}

University of Wollongong, Wollongong, New South Wales, Australia

Australian National Centre for Ocean Resources and Security (ANCORS)

Level 3, Building 233 (ITAMS Building)

Innovation Campus, University of Wollongong

Squires Way

North Wollongong, NSW 2500

Australia

Corresponding Author: Prakash Gopal

Email for correspondence: pgopal@uow.edu.au

\section{Bios}

Prakash Gopal is a former Indian Navy officer - currently pursuing his $\mathrm{PhD}$ at the Australian National Centre for Ocean Resources and Security (ANCORS), University of Wollongong. During his 21-year naval career, he commanded an anti-submarine corvette in Mumbai, and was involved extensively in policy formulation at headquarters. Prior to his voluntary retirement in 2018, he was a Research Fellow at the National Maritime Foundation - a maritime-focussed thinktank in New Delhi.

Orcid: https://orcid.org/0000-0002-1954-1689

Twitter: @FathomsOne

LinkedIn: https://www.linkedin.com/in/prakash-gopal/

Indra Alverdian is a PhD Candidate at the Australian National Centre for Ocean Resources and Security (ANCORS), University of Wollongong, Australia. He is a lecturer at the International Relations Programme, President University in Indonesia with specialization in maritime security and defence policies of Southeast Asian countries. He has been involved in policy research on security and defence at government, legislative and non-governmental institutions in Indonesia. He is a Visiting Research Fellow for the Sea Programme at Abo Akademi University, Finland and a Research Associate at the Corbett School for Maritime Policy, Kings College, UK.

Orcid: https://orcid.org/0000-0003-1214-5074

Funding Details: None applicable

Disclosure Statement: No potential conflict of interest to declare

Number of Words: 8592 (including references and endnotes) 


\section{Maritime security cooperation between India and Indonesia - imperatives, status and prospects}

India and Indonesia are two key emerging economies in the Indo-Pacific region both with a strong reliance on the maritime domain for sustained economic growth. After a relatively tumultuous phase in their bilateral relations during the Cold War, the countries have embarked on a path of reconciliation and developing stronger ties.

During this phase there has understandably been a strong focus on enhancing maritime security cooperation between them, so as to obtain positive bilateral and regional outcomes. This has gained impetus in recent years with congruence of thought at the political level in both New Delhi and Jakarta. However, the many institutional mechanisms developed over the years have not been as effective in engendering tangible security outcomes in the region. Both countries - and indeed the Indo-Pacific region - would decidedly benefit from focusing on key areas of cooperation in maritime security, that promise mutually beneficial operational outcomes, and the prospect of establishing long-term cooperative mechanisms in the Indo-Pacific region.

Keywords: India; Indonesia; maritime security; Indo-Pacific

\section{Introduction}

India and Indonesia are the two most populous countries in the Indian Ocean Region (IOR). Besides being demographically significant, geography has afforded to these countries the prospect of exerting greater influence than they have thus far been capable or willing to attempt. The Indian peninsula occupies a dominant position in the eponymous ocean, proximate to critical shipping lanes that fuel Asia's economic growth. The Indonesian archipelago sits at the confluence of the Indian and Pacific Oceans, and the South China Sea, thus placed at the pivot of the Indo-Pacific region. While each of these countries have significant untapped potential, the prospect of what they may achieve through collaboration and cooperation - especially in the maritime domain - is even more promising. 
The 1951 treaty of friendship between India and Indonesia commits to 'perpetual peace and unalterable friendship' between the two countries (Government of India: Ministry of External Affairs, 1951). India's support for Indonesia's independence from the Dutch, and the personal relations between Nehru and Sukarno brought much zeal to bilateral engagement (Brewster, 2011, p. 222). This bonhomie peaked in 1955 at the Bandung conference, and went on to lay the foundations of the Non-Aligned Movement (Acharya, 2016, p. 347). Relations between India and Indonesia soured in the 1960s, driven by a series of events that brought fundamental ideological differences to the fore, and created an atmosphere of mutual suspicion. ${ }^{1}$ Bilateral ties remained lukewarm at best for over three decades thence, until the end of the Cold War in 1991, and the subsequent resignation of Suharto in 1998 (Supriyanto, 2013). Many steps have since been taken in an attempt to elevate India-Indonesia bilateral ties, with the maritime domain offering significant potential for growth, and yet remaining somewhat underdeveloped on both sides.

This paper seeks to explore facets of maritime security where India and Indonesia may achieve the greatest return on efforts to collaborate. In doing so, it will examine the imperatives for maritime security engagement between these two vital Indo-Pacific players, and articulate some of the larger regional outcomes that may be facilitated by a more robust partnership. The paper will also study existing instruments that seek to enable bilateral engagement in the maritime security domain, and examine their efficacy in achieving their stated objectives. Finally, the paper will offer potential avenues for collaboration and cooperation between the maritime security agencies of India and Indonesia that could lead to tangible positive operational and strategic outcomes.

\section{Imperatives for India-Indonesia maritime security cooperation}

India and Indonesia are maritime neighbours in a region that has been described as a 'key 
driver of global politics' (Clinton, 2011). The need for maritime security cooperation between these countries stems from two broad factors. First, both countries rely on unimpeded access to the global commons to sustain economic growth, and to fulfil socioeconomic aspirations of their citizens. Second, significant security challenges in the IndoPacific region threaten the legitimate use of the oceans for economic activity, and impose substantial costs on littoral countries. Renewed awareness of vulnerabilities, and of limitations in national capacities to tackle threats early and effectively, are arguably the most compelling reasons to enhance maritime security cooperation between India and Indonesia.

Despite being maritime neighbours, India and Indonesia are yet to demarcate the boundary between their Exclusive Economic Zones (EEZ) (Mitra, 2018). Whereas the continental shelf boundary between these countries has been formalised, no agreement exists on demarcating the EEZ (US Department of State, 1981). As a maritime space within which states exercise sovereign rights for economic activities, the EEZ is of significant strategic importance to coastal states. The absence of a demarcated boundary complicates security and law enforcement operations, as ambiguous jurisdictional limits may engender illegal activities. Greater maritime security cooperation between Indian and Indonesian agencies can help establish a collaborative framework for law enforcement operations especially along a nebulous and uncertain maritime boundary.

The Indo-Pacific region has emerged in recent years as a strategic continuum comprising two oceanic spaces, and conceptualised around the remarkable economic growth of countries in its littoral. India and Indonesia are among the top five Asian economies, and are projected to be the fastest growing ones up to and beyond 2024 (International Monetary Fund, 2019, p. 151). The current leaders of these countries Prime Minister Narendra Modi of India, and President Joko Widodo (Jokowi) of Indonesia - were both re-elected in 2019 , on the basis of strong economic and security 
manifestos. Security of the maritime commons - the unimpeded access to which is critical to fulfilling these agendas - is a significant consideration for the political establishments in Delhi and Jakarta.

India and Indonesia are geographically placed such that they sit astride key shipping lanes traversing the Indo-Pacific region. Vital sea lines of communication lie close to the Indian peninsula, bearing the bulk of energy supplies to East and Southeast Asia (Rahman, 2013, p. 3). Navigable straits in the Indonesian archipelago permit the extension of these lines of communication into the South China Sea, and the Western Pacific Ocean. The vulnerability of these shipping lanes to various security threats is a major cause for concern for the energy-hungry economies of East and Southeast Asia (Cordner, 2011, p. 73). The ability and willingness of India and Indonesia therefore, to ensure good order at sea, and to maintain free flow of commerce along these shipping lanes, is vital for the entire Indo-Pacific region.

India and Indonesia share common perceptions on threats in the maritime domain (Government of India: Ministry of External Affairs, 2013). While Indonesia does not explicitly list its perceived threats from state actors, unresolved maritime disputes in the South China Sea, together with China's overt assertions of its claims therein, would figure high on the list of concerns for Indonesia (Gindarsah \& Priamarizki, 2015). The proximity of the 'nine-dash line' to Natuna islands, and tensions around recent Chinese provocations in the area, provide significant cause for concern to Indonesia (Widianto \& Costa, 2020). India's maritime security strategy is more explicit on the issue of threats emanating from other states, and says:

The likely sources of traditional threat would be from states with a history of aggression against India, and those with continuing disputes or maintaining adversarial postures to India's national interests. The traditional sources of threat could also extend to nations that have the capability to harm Indian interests and display inimical intent against India. The possibility of sudden politico-economic 
and military events leading to changes in the regional security environment would also need to be considered (Indian Navy, 2015, p. 37).

While India's greatest perceived threat is one that may emerge from a Sino-Pakistan nexus, especially along its land borders to the North (Pant \& Bommakanti, 2019, p. 837), its significant maritime interests demand a robust maritime strategy based on regional cooperation (Indian Navy, 2015, p. 10)

A related and relevant factor is that of capacity within each of these countries to tackle threats that they identify as significant in the maritime domain. The Indonesian government under Jokowi has set an ambitious national maritime agenda with the 'Global Maritime Fulcrum' doctrine (Sekretariat Kabinet Republik Indonesia, 2014), and it's amplifying sea policy document (Coordinating Ministry for Maritime Affairs of the Republic of Indonesia, 2017). While these articulate the ends quite clearly, they are somewhat silent on the means to attain these ends. This is particularly relevant in the context of maritime security as the large archipelagic span of Indonesia demands resources far greater that can be realistically deployed, in order to maintain a minimum level of good order (Goh, 2015, p. 5). The shortage of resources is exacerbated by an administrative and operational structure that is riddled by a multitude of agencies, often with overlapping and unclear charters (Agastia, 2017). For Indonesia to be able to realise its ambitious maritime policy, there seems to be an inescapable need to bolster capability - both in terms of organisational structures and materiel wherewithal.

India's maritime security apparatus also suffers from a shortfall in necessary capability. The Indian Navy - which is the lead agency for maritime security in the country - is grappling with shortage of adequate platforms to fulfil its stated mandate in the region (Gopal, 2020a). While India's military industrial complex is relatively more capable, it is beset by developmental delays that have caused expensive imports to become the primary means of fleet augmentation. India's aspiration to be a regional 
maritime power is also somewhat constrained by the simultaneous necessity to focus on low intensity maritime operations such as law enforcement in its littoral (Gopal, 2018). There is therefore an undeniable need for both countries to augment capabilities. Arguably the quickest means to alleviate these shortfalls is through enhanced bilateral cooperation in this domain.

\section{Current state of bilateral maritime security cooperation}

The post-Cold War period has been one of gradual reconciliation between India and Indonesia, and a slow but steady improvement in mutual perceptions. This is driven in part by the political leadership on both sides, and events that have created opportunities for cooperation.

\section{Political instruments enabling maritime security cooperation}

A series of policy initiatives and bilateral instruments underpin defence and security cooperation between India and Indonesia. India's turn to economic liberalisation in 1991 was accompanied by the articulation of its 'Look-East' policy (Haokip, 2011, pp. 243244), which sought to broaden India's engagement with Southeast Asian countries, and to integrate with their economies. In this effort India found an ally in Indonesia, which supported its membership to the ASEAN Regional Forum (ARF) in 1996, and played a pivotal role in the institution of the ASEAN-India summit in 2002, as well as India's participation in the East Asian Summit of 2005 (Brewster, 2011, p. 231).

At the bilateral level, a Defence Cooperation Agreement was signed in 2001 between the two countries during Prime Minister Vajpayee's visit to Indonesia (A. K. Das, 2013a, p. 131). This agreement committed both countries to information exchange, exercises, reciprocal visits, education, and training. It also sought to enhance cooperation in the areas of defence technology, human resource capacities and operational 
capabilities. While it took six years for this agreement to be ratified by the Indonesian Parliament (A. K. Das, 2013a, p. 131), one operational outcome that was instituted relatively quickly was the setting-up of the India-Indonesia Coordinated Patrols (CORPAT) at sea that commenced in 2002 (Brewster, 2012, p. 117).

In November 2005, President Yudhoyono visited India at the invitation of the Indian Prime Minister Manmohan Singh (Mohan, 2011, p. 1). At this meeting, both leaders agreed to transform bilateral relations into a 'New Strategic Partnership' (Government of India: Ministry of External Affairs, 2005b). This was based on a shared understanding of altering geopolitical and geo-economic dynamics in the region, as was evident in the joint statement, which said:

Realizing that they now face a world that is fundamentally different than the one when Indonesia and India first established diplomatic relations six decades ago, this Partnership calls for Indonesia and India to adapt and elevate their relations to take on present and future challenges. As the world's largest democracies, and as independent-minded nations with a long tradition of internationalism, the combined voice of Indonesia and India can make a difference in international affairs (Government of India: Ministry of External Affairs, 2005b).

Both leaders decided on increasing bilateral visits of defence officials, creating additional training and education opportunities, and the establishment of an annual India-Indonesia strategic dialogue. Specific to the maritime domain, the leaders agreed to 'enhance cooperation in capacity building, technical assistance and information sharing between their respective relevant agencies' (Government of India: Ministry of External Affairs, 2005b).

Two more meetings ensued between President Yudhoyono and Prime Minister Manmohan Singh between 2005 and 2013. In January 2011, President Yudhoyono was 
the Chief Guest at India's Republic Day event in New Delhi (Thayer, 2011, p. 340). The vision for the strategic partnership between India and Indonesia that emerged from this visit made a strong pitch for both countries to play an increasing role in the region. In this context, the joint statement said:

They [India and Indonesia] have responsibility for, and are capable of, responding to global and regional challenges, and they must play an active role in the promotion of democracy, peace and stability in Asia Pacific region and the world at large (Government of India: Ministry of External Affairs, 2011).

This was hitherto the strongest statement advocating an active role for Indonesia and India in the region - and with good reasons. While the financial crisis of 2008 caused global mayhem, China, India and Indonesia were the only Asian countries that recorded positive economic growth in 2008-09 (Basri \& Rahardja, 2010, pp. 78-79). China's maritime claims in the South China Sea had become increasingly vocal, and the United States had announced its 'pivot' to Asia (DeLisle, 2016, p. 146). There was much turmoil to be managed, and the political leadership in both India and Indonesia seemed to agree that both countries were ready to play more active roles in doing so. In this mission they saw value in bilateral collaboration.

2014 witnessed change in political leadership in both countries, and their first bilateral summit occurred in December 2016, when President Jokowi visited India. Maritime issues were high on the agenda for both leaders as President Jokowi had unveiled his vision of Indonesia as a 'Global Maritime Fulcrum' in 2014, and Prime Minister Modi had announced India's vision of 'Security and Growth for all in the Region' (with the acronym SAGAR, which translates to 'sea' in Hindi) during his visit to Mauritius in the previous year (Prime Minister's Office, 2015). It was therefore quite natural that the outcomes of their first bilateral summit would have a predominant 
maritime flavour. A joint statement on maritime cooperation was issued, which envisioned an $\mathrm{MoU}$ on maritime cooperation, commencement of a strategic dialogue, and a new defence cooperation agreement (Government of India: Ministry of External Affairs, 2016). There was much promise in the air, and it seemed that India and Indonesia were commencing a new chapter in their bilateral relations that would have a significant regional impact, visible, especially in the maritime domain.

This impetus carried on to the next meeting of these leaders, when Prime Minister Modi visited Indonesia in May 2018. Here they decided to establish a new comprehensive strategic partnership between the two countries, and also agreed on a shared vision of maritime cooperation in the Indo-Pacific region (Government of India: Ministry of External Affairs, 2018a). While this statement understandably referred to the Global Maritime Fulcrum and SAGAR visions, it also highlighted the importance of ASEAN centrality and neutrality. There were notable and specific references to areas of bilateral cooperation in the maritime domain such as: increasing maritime awareness, capacity building for maritime search and rescue and pollution control; and promoting cooperation between coast guards through the establishment of single points of contact, regular consultations, coordinated patrols and joint exercises.

A relatively recent development has been the bilateral agreement to establish maritime connectivity between the Andaman and Nicobar islands, and Aceh (Septiari, 2019). While this may not be directly linked to maritime security outcomes, it is likely to encourage greater engagement between maritime security agencies. The fact that the port on Sabang island - which is the Indonesian node in this proposed maritime link - is being built in partnership with India, makes it a significant strategic investment in bilateral engagement by both countries (Chaudhury, 2019). Increased maritime connectivity will unarguably lead to enhanced trade and people-to-people interaction, both of which will entail augmented security collaboration between maritime agencies in both countries. 
The series of political instruments negotiated between India and Indonesia over the years has led to the institutionalisation of more frequent functional engagements between these countries. A range of such interactions now dot the calendar, and have focussed on operationalising these instruments of cooperation. Some of these mechanisms - such as the India-Indonesia security dialogue, the Defence Ministers' dialogue, and the joint working group on counter-terrorism - have strong linkages with maritime security efforts in the Indo-Pacific region (Embassy of India: Jakarta, 2019).

\section{Operational maritime security cooperation outcomes}

The India-Indonesia CORPAT is arguably the most visible and enduring manifestation of maritime security cooperation between the two countries. The commencement of this exercise in 2002 - just a year after the defence cooperation agreement was signed between the two countries - may be attributed largely to India's concerns arising from the separatist movement in Aceh province of Indonesia (Brewster, 2012, p. 117). While Indonesia was understandably keen to quell this separatist movement, India was concerned that instability in that part of the region could pose serious challenges its regional maritime aspirations. Despite significant changes in the regional security outlook over the years, coordinated patrols between the two countries have endured, with its $34^{\text {th }}$ edition having been conducted in June 2020 (SpokespersonNavy, 2020).

Even as these coordinated patrols have sustained over time, their utility may be called to question. Despite being conducted regularly over the last 18 years, these patrols have witnessed negligible operational outcomes, and can be described as relatively lowlevel exercises between navies. A typical India-Indonesia CORPAT involves a mix of surface units and a maritime patrol aircraft on each side, patrolling on their respective sides of the International Maritime Boundary Line (IMBL). When they commenced in 2002, piratical activity in the Malacca Straits was on the rise, and separatist groups in 
Aceh were indulging in robbery at sea as a means of funding their movement (Brewster, 2012, p. 117). But 18 years later, the Aceh separatist movement has abated completely, and piracy is no longer a major concern in the Malacca Straits. In such a scenario the utility of the CORPAT, in which both sides retain their national command and control structures, and units operate on their side of the IMBL (Government of India: Ministry of Defence, 2019), is somewhat questionable. The types as well as numbers of ships and aircraft participating in these coordinated patrols has remained static over the years, pointing to an absence of incremental complexity in the exercise (See Table 1). Some additional elements such as combined visit, board, search and seizure exercises have been introduced over the years, but there is undoubtedly a strong case for re-evaluating the contours of this biannual engagement.

Table 1: Participation of naval units in last ten editions of the India-Indonesia CORPAT.

\begin{tabular}{|c|c|c|c|c|}
\hline $\begin{array}{l}\text { CORPAT } \\
\text { Edition }\end{array}$ & Year & Month & Indian Naval Units & TNI-AL (Indonesian Navy) Units \\
\hline 25 & 2015 & April & INS Saryu, Dornier aircraft & KRI Teuku Umar, CN235 aircraft \\
\hline 26 & 2015 & October & INS Saryu, Dornier aircraft & KRI Imam Bonjal, CN235 aircraft \\
\hline 27 & 2016 & May & $\begin{array}{l}\text { INS Karmuk, Dornier } \\
\text { aircraft }\end{array}$ & KRI Imam Bonjal, CN235 aircraft \\
\hline 28 & 2016 & October & $\begin{array}{l}\text { INS Karmuk, Dornier } \\
\text { aircraft }\end{array}$ & KRI Wiratno \\
\hline 29 & 2017 & May & $\begin{array}{l}\text { INS Karmuk, Dornier } \\
\text { aircraft }\end{array}$ & $\begin{array}{l}\text { KRI Sutedi Senaputra, CN235 } \\
\text { aircraft }\end{array}$ \\
\hline 30 & 2017 & October & INS Sukanya & KRI Imam Bonjal, CN235 aircraft \\
\hline 31 & 2018 & May & $\begin{array}{l}\text { INS Kulish, Dornier } \\
\text { aircraft }\end{array}$ & $\begin{array}{l}\text { KRI Sultan Thaha Syaifuddin, } \\
\text { CN235 aircraft }\end{array}$ \\
\hline 32 & 2018 & October & $\begin{array}{l}\text { INS Kulish, Dornier } \\
\text { aircraft }\end{array}$ & $\begin{array}{l}\text { KRI Kapitan Pattimaru, CN235 } \\
\text { aircraft }\end{array}$ \\
\hline 33 & 2019 & March & $\begin{array}{l}\text { INS Kesari, Dornier } \\
\text { aircraft }\end{array}$ & $\begin{array}{l}\text { KRI Sultan Thaha Syaifuddin, } \\
\text { CN235 aircraft }\end{array}$ \\
\hline 34 & 2020 & June & $\begin{array}{l}\text { INS Kulish, Dornier } \\
\text { aircraft }\end{array}$ & KRI Teuku Umar, CN235 aircraft \\
\hline
\end{tabular}

Source: Details of participating units for each edition of the CORPAT have been compiled from media reports, social-media posts, and official press statements of the Indian Navy at https://www.indiannavy.nic.in/press-release. Some inputs have also been directly obtained from Indian Navy's spokesperson by the author. 
A significant step in scaling up naval engagement between these countries was the introduction of a concurrent bilateral maritime security exercise, the first edition of which coincided with the CORPAT in October 2015 (Government of India: Ministry of Defence, 2015). There were two more instances of this exercise in 2016 (Indian Navy, 2016) and 2017 (Government of India: Ministry of Defence, 2017), both of which coincided with CORPATs in October of each year. In 2018 however, a new bilateral naval exercise called Samudera Shakti was introduced (Government of India: Ministry of Defence, 2018b). While the CORPAT and the earlier avatar of the bilateral exercise were largely focussed on maritime law enforcement, Samudera Shakti involved activities closer to the war-fighting end of the spectrum of maritime operations such as combined manoeuvres, air defence exercises, helicopter operations and weapon firing drills. The introduction of this new bilateral naval exercise may be the right catalyst to enhance naval cooperation and interoperability, and to break the repetitive and somewhat unrewarding biannual ritual of coordinated patrols. Much like India's bilateral naval exercises with the US Navy and the Singapore Navy that have evolved significantly in complexity over the years, there is potential for Samudera Shakti to transform into a multi-dimensional naval exercise in future. This would entail constructive commitment between the navies, and sustained political engagement between Delhi and Jakarta.

Greater operational engagement between the Indian Coast Guard and Indonesia's Badan Keamanan Laut (Bakamla) is also beginning to take shape. The first high level meeting between the heads of these organisations took place in New Delhi in December 2018 (Government of India: Ministry of Defence, 2018a). This meeting laid the groundwork for a memorandum of understanding that was signed in July 2020 between the maritime law enforcement agencies (Chaudhury, 2020). Preliminary exchanges have also occurred over existing exercises such as the Indian Coast Guard's national level 
pollution response exercise conducted in January 2019, at which Bakamla representatives were present as observers (India Strategic, 2019).

Besides structured exercises, there have been other windows of opportunity for maritime forces of India and Indonesia to interact. Most of these have arisen in the wake of natural disasters in Indonesia, which have elicited a Humanitarian Assistance and Disaster Relief (HADR) response from India. The Boxing Day tsunami of 2004 was arguably the most prominent of these. India provided significant assistance in its aftermath to all affected countries in the region, with the bulk of the assistance understandably directed to Indonesia. Among the five separate missions mounted by the Indian Navy, Operation Gambhir was targeted at providing succour to affected parts of Indonesia. Indian naval ships Khukri and Nirupak were despatched to Indonesia with 40 tonnes of relief material, arriving in early January 2005 (Embassy of India: Jakarta, 2014). Nirupak was modified as a hospital ship that continued to provide medical assistance off Aceh, complete with 50 beds and a fully-functional intensive care unit (Government of India: Ministry of External Affairs, 2005a). The Indian Navy was further involved in HADR missions to Indonesia in 2006 (A. K. Das, 2013b, p. 169), and as recently as in 2018 (Government of India: Ministry of External Affairs, 2018b). These missions underscored the necessity and effectiveness of international collaboration in HADR response in the region. The large-scale global relief operation in the wake of the 2004 tsunami also sowed the seeds for the 'Quad' - a grouping of Australia, India, Japan and the United States (Madan, 2017). What started off as an informal grouping to coordinate relief operations, has now arguably attained a strategic hue that may prove - somewhat ironically - to be an impediment to greater maritime engagement between India and Indonesia.

A number of factors reinforce the axiomatic belief that bilateral ties between India and Indonesia are vital for the growth and stability of the Indo-Pacific region. Among all 
facets of bilateral ties, cooperation in the maritime domain appears intuitively as one in which maximum gains may be obtained. There are two distinct strands along which IndiaIndonesia bilateral relations have progressed over the years: the strategic partnership driven by the political leadership, and the security relationship directed largely by their maritime forces. It is quite evident that the two have not progressed in tandem. At the strategic level, there is a clear recognition of the imperatives for stronger bilateral ties. There are other indicators, such as bilateral trade that have grown significantly over the years. The fact that the bulk of this trade is carried by sea, should have sufficiently catalysed greater synergy in maritime security and law enforcement operations. This has clearly not happened, and it may be useful to examine the major impediments to what appears to be, a natural partnership in the maritime domain.

\section{Impediments to enhancing India-Indonesia bilateral maritime security cooperation}

Divergent imperatives, derived from the dissimilar strategic cultures of India and Indonesia, may be the most significant factor preventing a closer alignment of their maritime security agendas. Two foundational aspects of Indonesia's strategic culture seem to shape its contemporary outlook. First, the importance it accords to the tenets of anti-imperialism and neutrality; and second, the vast archipelagic reality of the country which compelled its strategists to prioritise national cohesion over external power projection (Kilcullen, 2019, p. 46). Indian strategic thought has been described simultaneously as a somewhat muddled outcome of complex historical experiences; lacking in coherence and discipline; and largely land-oriented (Tanham, 1992, pp. 5054). As discussed earlier, greater political alignment between Delhi and Jakarta, together with imperatives arising from regional geopolitical developments, have nudged them towards a more active maritime role in the region. However, their 'geographical histories' 
continue to influence their outlook, and drive domestic and foreign policy compulsions that counteract other proactive and alternate approaches to maritime Indo-Pacific. ${ }^{2}$

If archipelagic considerations have been a priority for Indonesia's political establishment, continental imperatives have kept India's security architecture engaged since independence in 1947. India's wars with Pakistan (1947-48, 1965, 1971 and 1999) and China (1962), have understandably focussed much attention to its northern land frontiers, at the expense of the development of its maritime potential (Rehman, 2017, pp. 227-229). Even today, tensions along the Line of Actual Control between India and China, and the threat of cross-border terrorism from Pakistan, keep much of the focus towards the terrestrial North, at the expense of the maritime South. While there is political recognition of India's significant maritime interests, and the importance of investing in their defence, these come a distant second to terrestrial considerations. This has undoubtedly constrained the Indian Navy and Indian Coast Guard's ability to engage effectively with India's maritime neighbours.

Another aspect that may be responsible for insufficient momentum in improving bilateral maritime security cooperation is the complex yet contrasting nature of civilmilitary relations in both countries. The armed forces of Indonesia were deeply enmeshed in domestic social and political matters as per the dual-function (dwifungsi) doctrine (Jenkins, 1983, p. 22). Despite revocation of this doctrine in the reformation era (Reformasi) after 1998, the Indonesian military - especially the Indonesian Army remains an influential actor in the national political landscape (Laksmana, 2019b, p. 807). President Jokowi too has steered clear of any controversial policies that may affect the armed forces, and has in fact allowed them to expand their portfolio of non-military activities (Laksmana, 2019a, pp. 68-70). In such circumstances, the Indonesian navy has preferred to focus primarily on maritime law enforcement and internal security, so as to maintain internal domestic relevance. (Arif \& Kurniawan, 2017). In India, civil-military 
relations take on a somewhat different hue. While organisational structures enable civilian oversight of military matters, there is little investment and engagement in strategic issues from the civilian side. This has largely been attributed to lack of domain expertise, experience, and continuity within the civilian cadre - across both the political leadership and the bureaucracy (Mukherjee, 2014, p. 201). Conversely, the armed forces play an insignificant role in the strategic decision-making process within the government. Combined with the dominant land-centric view of security issues, this has adversely impacted India's maritime outreach. India's relatively advanced maritime outlook, and a nuanced maritime strategy owes its existence to the Indian Navy that was often at loggerheads with the civilian establishment in pursuing them (Brewster, 2010, p. 4). The relative positions of maritime security agencies within executive structures in India and Indonesia, have arguably contributed to the stagnation of navy-to-navy engagement, and the total absence - until recently - of any meaningful interaction between maritime law enforcement agencies of these countries.

Discordant perceptions of the Indo-Pacific as a strategic space have arguably slowed the pace at which maritime security collaboration has progressed between these countries. Indonesia's reservations on the role of 'outsiders' in its archipelagic backyard has been a consistent feature of its foreign policy doctrine that has 'independent and active' as a prominent subtext (Hermawan, 2014, p. 61). In 1957, the country sought to assert sovereignty over the Malacca Straits - a move that has been described as a 'postcolonial state's attempt to come to terms with keeping imperial potentialities at bay on its proximate waterways' (Chong, 2006, p. 131). It has therefore consistently opposed the presence of extra-regional powers in its neighbourhood, in the context of which Leifer (1974) stated: 
Ultimately, however, the Indonesian Government envisages the removal of all extra-regional military presences from its strategic environment, and in this respect one might take note of the publicly expressed disapproval of President Suharto at the prospect of the further development of the island of Diego Garcia in the Indian Ocean as a military facility under Anglo-American auspices.

Indonesia's misgivings at being entangled in a great-power competition in the region is also conveyed in its belated definition of the Indo-Pacific construct - one which has a notable ASEAN focus - in contrast to the Japan-US led 'Free and Open Indo-Pacific' concept (Anwar, 2020, p. 127). While yet unstated officially, Indonesia's position on the Quad has been described as a 'potential strategic coalition of outside powers without ASEAN's involvement' (Acharya, 2019). However, Indonesia's overall position on the presence of extra-regional maritime powers has clearly evolved in the post-Cold War period. It has welcomed President Obama's rebalance to Asia, and considers the United States' maiden participation in the East-Asia summit of 2011 as an important milestone (Anwar, 2020, p. 122). But its evolving views on the Quad will have implications on its bilateral ties with India, depending on how the framework evolves, and the consequent impact on Indonesia's core concerns.

Historical baggage, lack of rapport among political leaders, and the absence of an enduring strategic vision of the region are other factors that are often offered as reasons for the underwhelming progress on this front. It may therefore be of greater utility to focus on the operational necessity for both countries to ensure security of the maritime commons as the driver for greater collaboration in relatively smaller, but meaningful ways. Parallels may also be drawn here with India-US naval ties that started tentatively in the 1990 s with a rudimentary naval exercise that eventually led to redefining bilateral ties, despite serious political bottlenecks (Khurana, 2008, pp. 1048-1049). With India and Indonesia, the challenges are certainly not as formidable, and there are undoubtedly 
greater incentives for achieving positive operational outcomes in the shared Indo-Pacific region.

\section{Potential avenues for bilateral maritime security cooperation between India and Indonesia}

Considering the importance of good order at sea for India and Indonesia, maritime law enforcement may be an area of collaboration with significant mutual benefits. It is vital for both countries to be able to deter, detect and defeat nefarious activities that disrupt good order, and pose challenges to the legitimate use of the seas for social and economic purposes. Maritime agencies of both countries recognise the significant opportunities and benefits that may accrue from a collaborative approach to law enforcement efforts in the regional commons. This is evidenced in the recently concluded memorandum of understanding between the Indian Coast Guard and Bakamla that seeks to develop bilateral cooperation with the stated aim of

...enhancing collaborative and cooperative engagements in the domains of maritime law enforcement, maritime search and rescue, and marine pollution response. This is likely to entail exchange of information towards combating transnational maritime crimes, facilitation of coordinated search \& rescue operations at sea and conduct of capacity \& capability building activities (Indian Coast Guard, 2020).

Several measures may be adopted to catalyse collaborative maritime law enforcement operations between India and Indonesia. It may be useful to delegate the conduct of CORPAT to maritime law enforcement agencies organisations, allowing the navies to consolidate interoperability at the higher end of the spectrum of operations. With the recent establishment of Indonesia's Maritime Information Centre in July 2020, there exists significant potential for collaboration in the exchange of maritime law enforcement 
information (Nirmala \& Long, 2020). Both countries could also work on developing specific protocols for managing instances of IUU fishing, considering that the EEZ boundary between these countries is yet to be demarcated. Other aspects of maritime law enforcement such as prevention of trafficking and conformity to environmental regulations could progressively be incorporated into the bilateral agenda.

There are shared concerns that could also benefit from collaboration at the higher end of the maritime security spectrum of operations. Both countries have faced deadly terrorist attacks along their coasts. The Mumbai terrorist attacks of 2008, and the Bali bombings of 2002 and 2005, caused significant damage to the maritime economies of India and Indonesia. Understandably, both countries are concerned about the possibility and potential repercussions of future terrorist attacks, but are simultaneously confronted by shortfalls in capacity to prevent these. It may be expedient to leverage the IndiaIndonesia Joint Working Group on counter-terrorism to evolve specific lines of operation in the maritime domain that could deter and defeat a potential act of maritime terrorism. ${ }^{3}$ These could include, intelligence-sharing mechanisms, table-top exercises, joint training, exercises between maritime counter-terrorism forces, and the sharing of best practices in surveillance, intelligence and interdiction operations. These models could be extended to other maritime law enforcement operations such as anti-trafficking and anti-narcotics operations. Possibly the best means of kick-starting this would be with a series of periodic engagements between operational authorities, with an unambitious agenda to start with one that has tangible outcomes for both sides.

For evolving a realistic and sustainable model of engagement in cooperative maritime security, it may be useful for India and Indonesia to start with modest goals, and progressively scale up the frequency and complexity of interactions. The Samudera Shakti series of bilateral naval exercises offer significant potential therein. In contrast to multilateral exercises like Milan or Komodo, the bilateral exercise format is an invaluable 
training opportunity, and must be utilised as such. ${ }^{4}$ While these may appear somewhat rudimentary in their current form, they will go a long way in establishing trust, and achieve a level of interoperability that can be used as a foundation to base more complex, multi-platform and multi-domain exercise scenarios. Sustaining this periodic formal engagement between the navies - year after year - would be central to augmenting maritime security cooperation between India and Indonesia.

Maritime domain awareness (MDA) offers a graded and easily implementable framework for bilateral collaboration. It is a vital element of maritime security operations, one that is particularly challenging for both India and Indonesia. While modern technology has automated the process of information gathering to a large extent, there exist considerable challenges in the IOR and in Southeast Asia, where a number of smaller craft operate at sea with little or no means of electronic identification. India has a reasonably well-established system of 'white-shipping' information exchange with a number of countries (Gopal, 2020b, pp. 7-8), but has no such institutionalised arrangement with Indonesia, despite these countries being maritime neighbours. The shared vision statement of India-Indonesia maritime cooperation in the Indo-Pacific also highlights the need to enhance information sharing mechanisms related to maritime security. The early conclusion of a formal information sharing arrangement will significantly enhance domain awareness outcomes for both countries, especially in the sea areas around their shared maritime boundary.

India and Indonesia could construct collaborative MDA efforts around the Information Fusion Centre-Indian Ocean Region (IFC-IOR) established by India in December 2018, the primary stated aim of which is:

To advance Maritime Safety and Security in the Indian Ocean Region; by enhancing maritime domain awareness and coordinating activities, through information 
sharing, cooperation and expertise development; along with partner nations and agencies (Indian Navy, 2018).

Similar in concept to the Information Fusion Centre in Changi, Singapore, this facility is also designed to host liaison officers from other countries to provide a pool of information collectors, analysts, and disseminators. While yet at a nascent stage, the appointment, in future, of an Indonesian liaison officer to this facility would contribute significantly to collective domain awareness efforts in the region, and could be further augmented by a reciprocal hosting of an Indian liaison officer at the Indonesian Maritime Information Centre. As a second order effect, this will enhance mutual trust between maritime security agencies of both countries, laying the foundation for greater collaboration in the future.

Associated closely with the function of maritime domain awareness, is the management of coastal areas, and the integration of coastal communities in the overall national maritime security frameworks. Both India and Indonesia have a rich repository of best practices in this regard. After the Mumbai terror attacks of November 2008, India introduced a slew of measures aimed at improving its coastal security wherewithal (P. Das, 2013, pp. 58-65). A key reform initiative that received significant impetus in the wake of this attack is the Coastal Security Scheme that decentralises several security functions, by integrating coastal communities into the security framework. It complements other means of information gathering such as the chain of coastal sensors and the surveillance effort by naval and coast guard assets. This has proved to be a successful model. Indonesia has also sought to improve outcomes of its maritime security efforts, especially those targeting IUU fishing. This has involved disentangling overlapping jurisdictions of its myriad maritime agencies, as well as a focus on educating and engaging with coastal communities as major stakeholders (Chapsos, Koning, \& Noortmann, 2019). There is significant commonality in the approaches and desired end- 
states of the maritime security efforts of India and Indonesia. An institutional mechanism for exchange of best practices, as may be obtained through participation in exercises, exchange of personnel for training as well as operations, and periodic meeting of minds to discuss problem areas, would serve both countries well.

\section{Conclusion}

There are many compelling reasons for greater cooperation between India and Indonesia, particularly in the maritime domain. As maritime neighbours that are both dependent heavily on maritime trade for economic growth, they have significant interests in ensuring good order upon the regional maritime commons. The importance of the Indo-Pacific as a predominant maritime region, and its increasing strategic salience, makes maritime security cooperation between India and Indonesia, an exigent necessity.

The maritime domain offers the most promising and productive canvas for cooperation between India and Indonesia. The current democratically elected leadership in both countries has won clear mandates for developmental agendas, premised heavily on the ability of these states to utilise the seas for social and economic development. Both countries face daunting challenges in the maritime domain exacerbated by individual capacity shortfalls that are unlikely to be overcome individually by each of the countries. The strategic partnership between the two countries has a significant maritime focus that is evidenced in the shared vision of maritime cooperation in the Indo-Pacific region, announced in 2018. Cooperation in the field of security is a critical component of this shared vision.

In keeping with the political tempo of bilateral relations, the frequency and tenor of interaction between the maritime security agencies of India and Indonesia have witnessed significant reinvigoration in recent years. But most interactions appear to be heavy on symbolism, with arguably inadequate operational or long-term outcomes. 
Bilateral maritime exercises - such as the coordinated patrol between the two navies have been in place for a long time, but have not evolved significantly in scale and complexity. Other avenues of cooperation such as maritime law enforcement, domain awareness and coastal management have hitherto remained somewhat under-developed, and offer immense potential for enhanced bilateral engagement. Besides being necessary, these areas also present themselves as the proverbial low-hanging fruit that both countries can pick with relative ease, cementing a closer strategic partnership in the process - one that can have significant positive outcomes for the Indo-Pacific region. 


\section{References}

Acharya, A. (2016). Studying the Bandung conference from a Global IR perspective. Australian Journal of International Affairs, 70(4), 342-357.

Acharya, A. (2019, August 11). Why ASEAN's Indo-Pacific outlook matters. East Asia Forum. Retrieved from https://www.eastasiaforum.org/2019/08/11/why-aseansindo-pacific-outlook-matters/

Agastia, I. G. B. D. (2017, November 22). 3 Years Later, Where Is Indonesia's 'Global Maritime Fulcrum'? The Diplomat. Retrieved from https://thediplomat.com/2017/11/3-years-later-where-is-indonesias-globalmaritime-fulcrum/

Anwar, D. F. (2020). Indonesia and the ASEAN outlook on the Indo-Pacific. International Affairs, 96(1), 111-129.

Arif, M., \& Kurniawan, Y. (2017). Strategic Culture and Indonesian Maritime Security. Asia \& the Pacific Policy Studies, 5(1).

Basri, M. C., \& Rahardja, S. (2010). The Indonesian economy amidst the global crisis: good policy and good luck. ASEAN Economic Bulletin, 7(1), 77-97.

Brewster, D. (2010). An Indian Sphere of Influence in the Indian Ocean? Security Challenges, 6(3), 1-20.

Brewster, D. (2011). The Relationship between India and Indonesia: An Evolving Security Partnership? Asian Survey, 51(2), 221-244.

Brewster, D. (2012). India as an Asia Pacific Power: Taylor \& Francis.

Chapsos, L., Koning, J., \& Noortmann, M. (2019). Involving local fishing communities in policy making: Addressing Illegal fishing in Indonesia. Marine Policy, 109.

Chaudhury, D. R. (2019, March 20). Eyeing Southeast Asia, India builds port in Indonesia. The Economic Times. Retrieved from https://economictimes.indiatimes.com/news/defence/eyeing-southeast-asiaindia-builds-port-in-indonesia/articleshow/68490478.cms? from $=\mathrm{mdr}$

Chaudhury, D. R. (2020, July 7). Indian, Indonesian Coast Guards sign MoU to uphold rules-based order in the Indo-Pacific region. The Economic Times. Retrieved from https://economictimes.indiatimes.com/news/defence/indian-indonesiancoast-guards-sign-mou-to-uphold-rules-based-order-in-the-indo-pacificregion/articleshow/76840243.cms\#: :text=Bakamla\%20RI\%20(Indonesian\%20 Coast $\% 20$ Guard,through $\% 20$ telepresence $\% 20$ on $\% 20$ July $\% 206$.

Chong, A. (2006). Michael Leifer and the security of Southeast Asia's maritime thoroughfares. In M. Leifer, J. C. Liow, \& R. Emmers (Eds.), Order and security in Southeast Asia : Essays in memory of Michael Leifer: Routledge.

Clinton, H. (2011, October 11). America's Pacific Century. Retrieved from https://foreignpolicy.com/2011/10/11/americas-pacific-century/

Coordinating Ministry for Maritime Affairs of the Republic of Indonesia. (2017). Indonesian Ocean Policy. Jakarta: Government of Indonesia.

Cordner, L. (2011). Progressing Maritime Security Cooperation in the Indian Ocean. Naval War College Review, 64(4), 68-88.

Das, A. K. (2013a). India's Defense-Related Agreements With ASEAN States: A Timeline. India Review, 12(3), 130-133.

Das, A. K. (2013b). Soft and Hard Power in India's Strategy Toward Southeast Asia. India Review, 12(3), 165-185.

Das, P. (2013). Coastal Security: the Indian experience. New Delhi: Institute for Defence Studies and Analyses.

DeLisle, J. (2016). International law in the Obama administration's pivot to Asia: the China Sea disputes, the Trans-Pacific partnership, rivalry with the PRC, and 
status quo legal norms in U.S. foreign policy. Case Western Reserve Journal of International Law, 48(1/2), 143-176.

Embassy of India: Jakarta. (2014). Government of India expresses solidarity with the government and the people of Indonesia on the solemn occasion of Indian Ocean Tsunami Disaster commemoration [Press release]. Retrieved from https://mea.gov.in/Portal/CountryNews/3398 Press_Release -

Government_of_India expresses solidarity with the Government and the $p$ eople of Indonesia on the solemn occasion of Indian Ocean Tsunami Disa ster commemoration.pdf

Embassy of India: Jakarta. (2019). India-Indonesia Bilateral Brief. Retrieved from https://www.indianembassyjakarta.gov.in

Gindarsah, I., \& Priamarizki, A. (2015). Indonesia's Maritime Doctrine and Security Concerns. RSIS Policy Report, 9(9).

Goh, E. (2015). Indonesia's new strategic policy under Jokowi: change, continuity, and challenges. In A. Carr (Ed.), A Strategy towards Indonesia. Canberra: ANU.

Gopal, P. (2018, September 11). India's Navy: Between Carriers and Patrol Boats. The Interpreter. Retrieved from https://www.lowyinstitute.org/the-interpreter/indias-navy-between-carriers-and-patrol-boats

Gopal, P. (2020a, January 23). India: Navigating the Straits of Capability. The Interpreter. Retrieved from https://www.lowyinstitute.org/the-interpreter/indianavigating-straits-capability

Gopal, P. (2020b). Maritime domain awareness and India's maritime security strategy: Role, effectiveness and the way ahead. Maritime Affairs: Journal of the National Maritime Foundation of India, 16(2), 1-12.

Government of India: Ministry of Defence. (2015, October 3). Inaugural India Indonesia Bilateral Maritime Exercise. Retrieved from https://pib.gov.in/newsite/PrintRelease.aspx?relid=128415

Government of India: Ministry of Defence. (2017, October 24). INS Sukanya at Indonesia for Coordinated Patrol of IMBL. Retrieved from https://pib.gov.in/newsite/PrintRelease.aspx?relid=171888

Government of India: Ministry of Defence. (2018a, December 17). High Level Meeting Between Indian and Indonesia Coast Guard. Retrieved from https://pib.gov.in/PressReleaseIframePage.aspx?PRID=1556298

Government of India: Ministry of Defence. (2018b, November 12). INS Rana at Surabaya to participate in Indian Navy - Indonesian Navy Bilateral Exercise ‘ Samudra Shakti'. Retrieved from https://pib.gov.in/Pressreleaseshare.aspx?PRID $=1552528$

Government of India: Ministry of Defence. (2019, March 19). 33rd Edition of IndiaIndonesia Coordinated Patrol (Ind-Indo Corpat) Commences at Port Blair. Retrieved from https://pib.gov.in/Pressreleaseshare.aspx?PRID=1569122

Government of India: Ministry of External Affairs. (1951, March 3). Treaty of Friendship between India and the Republic of Indonesia. Retrieved from https://mea.gov.in/bilateraldocuments.htm?dtl/6699/treaty + of + peace + and + friendship

Government of India: Ministry of External Affairs. (2005a). Bridging the Ocean: India leads relief measures in tsunami hit areas. New Delhi: External Publicity Division.

Government of India: Ministry of External Affairs. (2005b, November 23). Joint Declaration between the Republic of India and the Republic of Indonesia. Retrieved from https://mea.gov.in/bilateral- 
documents.htm?dtl/7067/Joint+Declaration+between+the+Republic +of +India $+\mathrm{a}$ nd+the + Republic + of + Indonesia

Government of India: Ministry of External Affairs. (2011, January 25). Joint Statement: Vision for the India-Indonesia New Strategic Partnership over the coming decade. Retrieved from https://mea.gov.in/bilateral-

documents.htm?dtl/3143/Joint+Statement+Vision+for+the+IndiaIndonesia+New + Strategic + Partnership + over + the + coming + decade

Government of India: Ministry of External Affairs. (2013, October 11). Joint Statement - Five initiatives for strengthening the India-Indonesia Strategic Partnership.

Retrieved from https://mea.gov.in/in-focusarticle.htm?22318/Joint + Statement ++ Five + initiatives + for + strengthening + the + In diaIndonesia+Strategic+Partnership

Government of India: Ministry of External Affairs. (2016, December 12). IndiaIndonesia Joint Statement during the State visit of President of Indonesia to India. Retrieved from https://mea.gov.in/bilateraldocuments.htm?dt1/27805/IndiaIndonesia + Joint + Statement + during + the + State $+\mathrm{v}$ isit + of + President + of + Indonesia + to + India

Government of India: Ministry of External Affairs. (2018a, May 30). India-Indonesia Joint Statement during visit of Prime Minister to Indonesia (May 30, 2018). Retrieved from https://www.mea.gov.in/bilateraldocuments.htm?dtl/29932/IndiaIndonesia+Joint+Statement+during+visit+of+Pri $\underline{\text { me+Minister+to+Indonesia+May+30+2018 }}$

Government of India: Ministry of External Affairs. (2018b, October 3). Operation Samudra Maitri: India's Assistance to Earthquake and Tsunami affected areas in Indonesia. Retrieved from https://www.mea.gov.in/press-

releases.htm?dtl/30461/Operation_Samudra_Maitri_Indias_Assistance_to_Earth quake and Tsunami_affected_areas_in_Indonesia

Haokip, T. (2011). India's Look East Policy:Its Evolution and Approach. South Asian Survey, 18(2), 239-257.

Hermawan, Y. P. (2014). Indonesia in international institutions:: Living up to ideals. In C. B. Roberts, A. D. Habir, \& L. C. Sebastian (Eds.), Indonesia at Home and Abroad (pp. 59-66). Canberra: Australian National University.

Holmes, J. R. (2013, April 19). India has a Strategic Culture. The Diplomat.

India Strategic. (2019, January). Seventh National Level Pollution Response Exercise (NATPOLREX-VII) at Mumbai. Retrieved from https://www.indiastrategic.in/2019/01/08/seventh-national-level-pollutionresponse-exercise-natpolrex-vii-at-mumbai/

Indian Coast Guard. (2020, July 8). Signing of MoU between Indian Coast Guard and Indonesia Coast Guard. Retrieved from https://indiancoastguard.gov.in/WriteReadData/Tender/20200708095338921275 3PRESS_BRIEF.pdf

Indian Navy. (2015). Ensuring Secure Seas: Indian Maritime Security Strategy. New Delhi: Directorate of Strategic Concepts and Transformation.

Indian Navy. (2016). Coordinated Patrol and India-Indonesia Bilateral Maritime Exercise commence at Belawan, Indonesia. Retrieved from https://www.indiannavy.nic.in/content/coordinated-patrol-and-india-indonesiabilateral-maritime-exercise-commence-belawan

Indian Navy. (2018). Mission Statement: Information Fusion Centre - Indian Ocean Region. Retrieved from https://www.indiannavy.nic.in/ifc-ior/missionstatement.html 
International Monetary Fund. (2019). World Economic Outlook: Global Manufacturing Downturn, Rising Trade Barriers. Washington D.C.

Jenkins, D. (1983). The Evolution of Indonesian Army Doctrinal Thinking: The Concept of "Dwifungsi". Southeast Asian Journal of Social Science, 11(2).

Khurana, G. S. (2008). India-US Combined Defence Exercises: An Appraisal. Strategic Analysis, 32(6), 1047-1065.

Kilcullen, D. (2019). Strategic Culture. In P. R. Mansoor \& W. Murray (Eds.), The Culture of Military Organizations (pp. 33-52). Cambridge: Cambridge University Press.

Laksmana, E. A. (2019a). Civil-Military Relations under Jokowi: Between Military Corporate Interests and Presidential Handholding. Asia Policy, 14(4), 63-71.

Laksmana, E. A. (2019b). Reshuffling the Deck? Military Corporatism, Promotional Logjams and Post-Authoritarian Civil-Military Relations in Indonesia. Journal of contemporary Asia, 49(5), 1-31.

Leifer, M. (1974). Indonesia's Regional Vision. The World Today, 30(10), 418-425.

Madan, T. (2017, November 16). The rise, fall, and rebirth of the 'Quad'. Retrieved from https://warontherocks.com/2017/11/rise-fall-rebirth-quad/

Mitra, D. (2018, May 30). In Indonesia, Modi will find good ties also mean a new pact for sharing oceans. The Wire. Retrieved from https://thewire.in/diplomacy/indiaindonesia-eez-continental-shelf

Mohan, C. R. (2011, February 1). India and Indonesia : a new strategic partnership? RSIS Commentaries. Retrieved from https://dr.ntu.edu.sg/bitstream/10356/94228/1/RSIS0102011.pdf

Mukherjee, A. (2014). Civil-Military Relations and Military Effectiveness in India. In R. Basrur, A. K. Das, \& M. S. Pardesi (Eds.), India's Military Modernization: Challenges and Prospects (pp. 196-229). New Delhi: Oxford University Press.

Nirmala, R., \& Long, D. (2020, July 23). Indonesia Launches Maritime Information Center to Tackle Crimes at Sea. Retrieved from https://www.benarnews.org/english/news/indonesian/Maritime-InformationCenter-07232020184427.html

Nugraha, P. (2018, May 1). 51 war vessels to participate in Lombok naval exercise. The Jakarta Post. Retrieved from https://www.thejakartapost.com/news/2018/05/01/51-war-vessels-to-participatein-lombok-naval-exercise.html

Pant, H. V., \& Bommakanti, K. (2019). India's national security: challenges and dilemmas. International Affairs, 95(4), 835-857.

Parameswaran, P. (2018, February 28). The Real Significance of India's MILAN Navy Exercise. The Diplomat. Retrieved from https://thediplomat.com/2018/02/thereal-significance-of-indias-milan-navy-exercise/

Prime Minister's Office. (2015, March 12). Text of the PM's remarks on the Commissioning of Coast Ship Barracuda. Retrieved from https://www.pmindia.gov.in/en/news_updates/text-of-the-pms-remarks-on-thecommissioning-of-coast-ship-barracuda/

Rahman, C. (2013). The Geopolitical Context. In T. G. Mahnken (Ed.), Indo-Pacific Maritime Security in the 21st Century: Proceedings of an International Conference. Newport: US Naval War College.

Rehman, I. (2017). India's fitful quest for seapower. India Review, 16(2), 226-265. doi:10.1080/14736489.2017.1313566

Sekretariat Kabinet Republik Indonesia. (2014, November 13). Pidato Presiden RI Joko Widodo Pada KTT ke-9 Asia Timur, di Nay Pyi Taw, Myanmar, 13 November 
2014. Retrieved from https://setkab.go.id/pidato-presiden-ri-joko-widodo-padaktt-ke-9-asia-timur-di-nay-pyi-taw-myanmar-13-november-2014/

Septiari, D. (2019, September 5). Indonesia, India to step up connectivity cooperation. The Jakarta Post. Retrieved from https://www.thejakartapost.com/news/2019/09/05/indonesia-india-to-step-upconnectivity-cooperation.html

Shekhar, V. (2010). India and Indonesia: Reliable Partners in an Uncertain Asia. AsiaPacific Review, 17(2), 76-98.

SpokespersonNavy [@indiannavy]. (2020, June 24). India - Indonesia Coordinated Patrol. Retrieved from https://twitter.com/indiannavy/status/1275433180829331457

Supriyanto, R. A. (2013). Indonesia and India: Toward a Convergent Mandala. India Review, 12(3), 207-224.

Supriyanto, R. A. (2014, March 29). 'Exercise Komodo' and the South China Sea. The Jakarta Post. Retrieved from

https://www.thejakartapost.com/news/2014/03/29/exercise-komodo-and-southchina-sea.html

Tanham, G. K. (1992). Indian Strategic Thought: An Interpretive Essay. Santa Monica: RAND Corp.

Thayer, C. A. (2011). The Rise of China and India: Challenging or Reinforcing Southeast Asia's Autonomy? In A. J. Tellis, T. Tanner, \& J. Keough (Eds.), Strategic Asia 2011-12: Asia Responds to Its Rising Powers-China and India: National Bureau of Asian Research.

US Department of State. (1981). Limits in the Seas - Continental Shelf Boundaries: India-Indonesia-Thailand. Washington, D.C.: Bureau of Intelligence and Research.

Widianto, S., \& Costa, A. B. D. (2020, January 8). Indonesia deploys fighter jets to Natuna in stand-off with China. The Sydney Morning Herald.

\section{Notes}

${ }^{1}$ The India-China war of 1962, the India-Pakistan wars of 1965 and 1971, and India's support for Malaysia during Indonesia's Konfrontasi, were a series of developments that contributed to the souring of bilateral relations between India and Indonesia starting in the 1960s. See Shekhar (2010) and Supriyanto (2013).

2 James R. Holmes used the terms 'historical-geography' and 'geographical-history' while describing influences on India's strategic culture. See Holmes (2013)

${ }^{3}$ The India-Indonesia Joint Working Group on counterterrorism was established as an outcome of the 2004 memorandum of understanding between the two countries pertaining to counterterrorism. The first meeting of this group was held in February 2005. The fifth, and most recent meeting of this group was held in New Delhi in September 2018. See Embassy of India: Jakarta (2019). 
${ }^{4}$ The Milan multilateral naval exercise is conducted by India, generally in the Andaman and Nicobar Islands. It started off as a modest effort in 1995 to operationalise India's 'Look-East' policy, with the first edition involving just four other countries, viz. Indonesia, Singapore, Sri Lanka and Thailand. Today it has evolved into a gathering of over 15 navies from across the Indo-Pacific region. See Parameswaran (2018). Exercise Komodo is a multilateral HADR exercise hosted by Indonesia. It was started in 2014, and the third edition of this exercise was held in 2018. See Supriyanto (2014) and Nugraha (2018). 